\title{
Metode Mengajar Yesus menurut Injil Markus
}

Rifky Serva Tuju

Sekolah Tinggi Teologi Erikson-Tritt, Manokwari

servatuyu00@gmail.com

\begin{abstract}
Choosing the right teaching method can have a significant impact on those desiring to teach, and appropriate teaching methods can also provide solutions for students as they apply what they are learning. If we look closely in the Gospel of Mark, Jesus used some very interesting methods in his teaching to reach his listeners. As teachers, we ought to make use of the example of Christ's teaching in developing our own teaching methods so that what we seek to communicate and how we communicate it can have a significant impact on our students.
\end{abstract}

Keywords: gospel of mark; Jesus' teaching; teaching methods

\begin{abstract}
Abstrak: Memilih metode mengajar yang tepat dapat memberikan dampak yang signifikan bagi para guru dalam mengajar. Selain dampak yang signifikan bagi guru, metode mengajar yang tepat juga dapat memberikan solusi bagi para siswa yang mengikuti pengajaran tersebut. Jika dicermati dalam kita Injil Markus Yesus menggunakan beberapa metode yang sangat menarik dalam pengajaran-Nya yang membuat ada banyak sekali orang yang ingin mendengarkan pengajaran dari Yesus. Sebagai pengajar patutlah mencontohi cara dan metode mengajar yang digunakan oleh Tuhan Yesus dalam mengajar sehingga pengajaran yang disampaikan dapat memberikan dampak yang signifikan bagi orang yang diajar.
\end{abstract}

Kata kunci: Injil Markus; metode mengajar; Yesus mengajar

\section{PENDAHULUAN}

Dalam suatu proses belajar mengajar yang paling mempengaruhi siswa dalam mengerti suatu pelajaran ialah cara atau metode yang dipakai seorang pengajar atau guru. Memilih suatu metode juga sangat mempengaruhi seorang murid dalam menangkap pelajaran tersebut. Seorang guru harus memilih metode mengajar yang tepat agar mencapai tujuan yang diinginkan oleh seorang guru tersebut. Seperti yang dikatakan oleh B. S. Sidjabat: setiap kegiatan mengajar memerlukan metode yang tepat dan relevan untuk mencapa tujuan. ${ }^{1}$

Metode juga adalah agar dapat mewujudkan pelayanan yang menjadi tujuan dari seorang guru. Seperti yang dikatakan oleh Homrighhausen yang dikutip oleh Daniel Nuharmara, yaitu metode adalah suatu pelayanan dan suatu pekerjaan yang aktif, yang kita lakukan untuk Tuhan dan sesama manusia agar kedua pihak dapat bertemu satu sama lain. Artinya bahwa metode dapat menolong peserta didik untuk benar-benar belajar firman Tuhan. ${ }^{2}$

${ }^{1}$ B. S. Sidjabat, Menjadi Guru Profesional (Bandung: Yayasan Kalam Hidup, 2000), 89.

2Daniel Nuharmara, Pembimbing PAK (Bandung: Jurnal Info Media, 2007), 135. 
Begitu pula dengan Yesus ketika mengajar murid-murid dan mengajar orang banyak. Yesus selalu menggunakan metode dalam mengajar. Menurut Kenneth 0. Gangel and Howard G. Hendricks dalam bukunya The Christian Educator's Handbook On Teaching mengatakan "Bahkan Yesus menggunakan beberapa metode dan tidak terikat pada satu metode saja. Dia beralih dengan sangat lembut dari yang dikenal ke yang tidak dikenal, dari yang sederhana ke hal-hal yang rumit, dari hal-hal yang konkret ke hal-hal yang abstrak." Suatu kebebasan yang sesungguhnya, muncul dalam kemampuan metodologisnya dan dengan objektivitas yang cukup jelas. Dia bukanlah seorang penghibur melainkan seorang pendidik. Dia menginginkan lebih dari perhatian yang besar. Dia menjanjikan untuk mengubah hidup. ${ }^{3}$

Agar dapat menggunakan metodologinya secara fleksibel, seseorang tidak hanya harus tahu apa yang dipelajarinya secara keseluruhan, dia juga harus memiliki tujuan yang ingin dicapainya ketika membimbing murid-muridnya. Tuhan kita mendorong secara informal tetapi bukan tanpa tujuan.

\section{METODOLOGI}

Studi penyelidikan dalam penulisan jurnal ini pertama penulis memakai metode induktif yaitu metode yang dilakukan dengan langkah mencari data dan fakta Alkitab, kemudian menarik kesimpulan berdasarkan data dan fakta yang ditemukan dalam Alkitab. ${ }^{4}$ Metode ini yang menjadi dasar penulis dalam menggali teks-teks isi Alkitab. Sehingga penulis mendapatkan fakta dan data yang akurat dan menjadikan Alkitab sebagai sumber utama bukan sumber pendukung dalam jurnal ini.

\section{PEMBAHASAN}

\section{Metode Mengajar Tuhan Yesus menurut Injil Markus Penulis Injil Markus}

Tidak banyak yang diketahui mengenai penulis injil Markus, namanya juga tidak pernah ditulis di dalam kitab ini. Namun dalam beberapa sumber buku menuliskan tentang injil ini. Menurut tradisi ia adalah Yohanes Markus. Markus berasal dari keluarga berada, karena ibunya mempunyai rumah dan memiliki budak. Hayes mengatakan bahwa ia adalah seorang "anak manja seorang janda kaya." Barnabas, saudara sepupunya, mungkin juga seorang yang berada karena ia menjual ladang "dan membawa uangnya itu, dan meletakannya didepan kaki rasul-rasul" (4:37). Mungkin mereka berasal dari Siprus, karena Barnabas juga berasal dari sana (4:36). Rupanya Markus dibesarkan dalam lingkungan yang menggabungkan kebudayaan dan agama. ${ }^{5}$

Injil ini tidak menunjukkan penulisnya. Tetapi bahwa penulis Injil ini adalah Markus, teman sekerja Petrus, tidak secara hangat dipersoalkan. Sekalipun nama

\footnotetext{
${ }^{3}$ http://pepak.sabda.org/25/nov/2004/anak_metode_mengajar_yesus

${ }^{4}$ Donna Crosnoy Sinaga, Kripsi Studi Eksegesis Theologis Model-model Pertanyaan Allah dan Refleksi Theologisnya Menurut Kejadian 3:8-13 (Jogjakarta: STTII, 2007), hlm. 7.

${ }^{5}$ Merrill C. Tenney, Survei Perjanjian Baru (Malang: Gandum Mas, 2009), hlm. 197-198.
} 
Markus adalah nama paling umum, namun hampir tidak ada keraguan bahwa Markus ini adalah 'Yohanes' yang juga disebut Markus, yang disebut delapan kali dalam PB. Ia adalah kemenakan Barnabas (Kol. 4:10), sedang pernyataan 1 Petrus 5:13 dapat berarti, bahwa ia bertobat berkat Petrus. ${ }^{6}$

\section{Waktu dan Tempat Penulisan}

Waktu dan tempat penulisan Injil ini ditulis ada banyak pendapat yang berbedabeda. Tulisan dari Ireneus mencatat setuju bahwa Injil ini ditulis setelah kematian Petrus, mungkin diantara 65 hingga $68 .{ }^{7}$ Graham Swift mengatakan penulisan kitab ini berkisar pada batas 35 tahun antara 40 dan 75 M. ${ }^{8}$ Pendapat yang lain juga dikemukakan oleh J. N. Geldenhuys. Ia mengatakan bahwa disini perlu dikemukakan bahwa tidak ada sesuatu apapun dalam Injil yang menuntut perhitungan waktu penulisan melebihi tahun $70 \mathrm{M} .{ }^{9}$

Pendapat dari Ireneus bahwa Markus menyusun Injilnya 'setelah kepergian (exodos) Petrus dan Paulus. ${ }^{10}$ Kebanyakan ahli, dengan mengikuti kesaksian kuno, memandang Roma sebagai tempat penulisan kitab ini. ${ }^{11}$ Bukti-bukti internal dari Injil ini sesuai dengan tradisi eksternal bahwa tempat penebar-luasan Injil ini adalah Roma. Tenney mengatakan Injil Markus memang ditujukan bagi orang awam yang belum mendengar tentang Injil yang bermental Romawi. ${ }^{12}$

\section{Maksud Dan Tujuan Penulisan}

Maksud dan tujuan dari Injil ini sangatlah jelas bahwa Yesus Kristus, Anak Allah. Guthrie mengatakan Salib dan kebangkitan merupakan unsur inti Injil ini. ${ }^{13}$ Pada tahun 60-an M, orang percaya diperlakukan secara kejam oleh masyarakat dan banyak diantaranya disiksa bahkan dibunuh di bawah pemerintahan kaisar Nero.

Menurut tradisi, diantara para syahid Kristen di Roma itu terdapat rasul Petrus dan rasul Paulus. Selaku salah seorang pimpinan gereja di Roma, Yohanes Markus digerakkan oleh Roh Kudus untuk menulis Injil ini sebagai suatu antisipasi yang bersifat nubuat atau tanggapan penggembalaan terhadap masa penganiayaan ini. Tujuannya ialah memperkuat dasar iman dalam orang percaya di Roma, dan jikalau diperlukan, mendorong mereka untuk dengan setia menderita demi Injil, dengan memperhadapkan kepada mereka kehidupan, penderitaan, kematian serta kebangkitan Yesus, Tuhan mereka. ${ }^{14}$

\section{Ciri Khas}

Pada dasarnya, R. A. Cole mengatakan; Markus adalah Injil yang paling gamblang dan ringkas dari semua Injil. Matius memuat banyak hal bersifat Yahudi yang tidak

${ }^{6}$ C. E. Graham Swift, Tafsiran Alkitab Masa Kini, peny., Harun Hadiwijonon (Jakarta: Yayasan Bina Kasih, 2012), 123.

7Tenney, Survei Perjanjian Baru, 200.

${ }^{8}$ Swift, Tafsiran Alkitab Masa Kini, 123.

9J. N. Geldenhuys, Ensiklopedi Alkitab Masa Kini (Jakarta: Yayasan Komunikasi Bina Kasih/OMF, 2000), 1:651.

${ }^{10}$ Swift, Tafsiran Alkitab Masa Kini, 123.

${ }^{11}$ Ibid.

12Tenney, Survei Perjanjian Baru, 201.

${ }^{13}$ Donald Guthrie, Pengantar Perjanjian Baru (Surabaya: Momentum, 2010), 47.

${ }^{14} \mathrm{http}: / /$ www.sabda.org/sejarah/artikel/pengantar_full_life_markus.htm 
muncul dalam Markus. Begitu juga dengan Lukas. Bagian akhir Markus yang tibatiba terhenti merupakan masalah tersendiri. Yaitu masalah naskah bukan teologis. ${ }^{15}$ Guthrie menyebutkan Anak Allah, Markus menyebut Yesus dengan gelar ini dikalimat pembukaan, maka gelar ini harus diasumsi memiliki pengaruh penting bagi narasi selanjutnya, khususnya gelar ini muncul sebanyak lima kali dalam Injil Markus. ${ }^{16}$

Ciri khas Injil ini ialah menonjolkan pribadi Kristus sebagai hamba Tuhan. Kemesiasan Yesus juga pun sangat nampak dalam Injil ini. ${ }^{17}$ Di dalam Injil Markus, pengajaran Yesus umumnya dicatat dalam latar narasi. Donald Guthrie mengatakan jika semua bagian tulisan didaktis Injil Markus disarikan, maka kita akan menemukan sekumpulan pengajaran yang mengesankan. ${ }^{18}$

\section{Metode Mengajar Tuhan Yesus \\ Definisi Metode}

Dalam sebuah proses pembelajaran, seorang pengajar pastilah memiliki cara tersendiri dalam melakukan pembelajarannya. Tidak mungkin seorang guru melakukan proses pembelajaran tanpa dasar yang jelas dan tersistematis. Tentulah ada patokan-patokan yang harus dipenuhi atau dipatuhi dalam melakukan sebuah pembelajaran supaya tujuan yang diharapkan terpenuhi. Itulah sebabnya seorang guru sangat memerlukan sebuah metode dalam menyejikan pelajaran. Berikut ini adalah beberapa metode menurut parah ahli.

Menurut Hebert Bisno (1968) yang dimaksud metode adalah teknik-teknik yang digeneralisasikan dengan baik agar dapat diterima atau dapat diterapkan secara sama dalam sebuah praktek, atau bidang disiplin dan praktek. Lebih dalam lagi menurut Hidayat $(1990 ; 60)$ kata metode berasal dari bahasa Yunani, methodos yang berarti jalan atau cara. Jalan atau cara yang dimaksud disini adalah sebuah upaya atau usaha dalam meraih sesuatu yang diinginkan. ${ }^{19}$

Hal serupa yang dikatakan oleh Sidjabat, metode dapat juga diartikan sebagai "teknik" atau "prosedur. ${ }^{20}$ Sedangkan Prof. H. D. Sudjana mengatakan bahwa teknik adalah prosedur yang sistematik sebagai petunjuk untuk meaksanakan tugas pekerjaan yang kompleks. ${ }^{21}$ Jadi cara seorang guru yang dipergunakan dalam mengajar agar proses transfer ilmu berjalan dengan mudah sehingga siswa menjadi lebih paham disebut sebuah metode mengajar.

Dari ketiga pendapat tersebut dapat diambil kesimpulan metode adalah suatu cara dalam menyampaikan materi pelajaran kepada siswa. Metode juga dapat dipergunakan oleh seorang pengajar sebagai jalan menuju keberhasilan dalam proses belajar mengajar. Pemilihan metode yang tepat juga akan berpengaruh terhadap hasil belajar siswa. Sangat

${ }^{15}$ R. A. Cole, Ensiklopedi Alkitab Masa Kini (Jakarta: Yayasan Komunikasi Bina Kasih/OMF, 2000), 32 .

${ }^{16}$ Guthrie, Pengantar Perjanjian Baru, 45.

${ }^{17}$ Swift, Tafsiran Alkitab Masa Kini, 126.

${ }^{18}$ Guthrie, Pengantar Perjanjian Baru, 43.

${ }^{19} \mathrm{http}: / /$ www.eurekapendidikan.com/2014/10/definisi-metode-menurut-para-ahli.html

${ }^{20}$ B. S. Sidjabat, Menjadi Guru Profesional (Bandung: Yayasan Kalam Hidup, 2000), 89.

${ }^{21}$ H. D. Sudjana, Metode dan Teknik Pembelajaran Partisipatif (Bandung: Falah Produktion, 2001), 13. 
pentingnya penggunaan metode dalam pembelajaran membuat pengajar haruslah pintarpintar dalam menentukan metode manakah yang sesuai dengan kondisi kelas yang sedang dia ajar.Semakin pandai seorang pengajar menentukan metode yang akan digunakan dalam pembelajaran, maka keberhasilan yang diperoleh dalam mengajar semakin besar pula. Dari sini kita dapat mengetahui seberapa pentingnya suatu metode dalam proses belajar-mengajar dan dalam mencapai sebuah keberhasilan dari proses belajar-mengajar.

\section{Tujuan Pengajaran Tuhan Yesus}

Salah satu hal yang sangat penting dalam hal mengajar ialah tujuan. J. M. Price mengatakan banyak guru kerja tahun demi tahun tanpa tujuan tertentu kecuali menyampaikan kepada murid-murid-Nya bahan pelajaran yang diserahkan kepada mereka. ${ }^{22}$ Tanpa tujuan guru tidak dapat mengajar dengan baik, bahkan murid yang diajar tidak akan menyukai pelayan yang diajarkan.

Oleh karena itu seorang guru haruslah memiliki pengajaran yang menarik dan memiliki tujuan yang benar. Sidjabat memberikan beberapa penjelasan megenai dimensi tujuan megajar seorang guru. (a) tujuan yang menunjuk kepada perubahan, dalam segi pengetahuan dan pengertian yang sering disebut tujuan kognitif. (b) perubahan dalam segi sikap hidup, emosi, kehendak lasim disebut afektif. (c) perubahan dalam segi keterampilan, kecekatan berbuat, tindakan nyata umumnya disebut tujuan psikomotoris atau konatif. ${ }^{23}$

Secara khusus tujuan pembelajaran yang dilakukan oleh Yesus adalah agar murid-murid-Nya mengenal Bapa di surga secara pribadi dan meyakini bahwa hanya Yesus satu-satunya jalan keselamatan serta dapat membawa orang lain kepada jalan keselamatan yang telah mereka temukan di dalam Yesus Kristus. ${ }^{24}$

Perilaku kebanyakan guru dimasa sekarang sangat kontras dengan apa yang dilakukan oleh Yesus. Dalam mengajar Yesus selalu mengutamakan tujuan pembelajaran apa yang harus dia ajarkan kepada murid-murid-Nya dan kepada orang banyak. Seperti yang dikatakan oleh Price ini, lain halnya dengan Yesus, Ia tidak pernah mengajar semata-mata karena Ia harus mengajar. Ia selalu mempunyai tujuan-tuan yang akan dicapainya. ${ }^{25}$ Tujuan itu berupa pelayanan dengan tujuan membawa siswa mengenal Kristus sebagai Tuhan.

\section{Karakter Tuhan Yesus}

Karakter seorang guru akan nampak ketika sedang mengajar. Dan Yesus memiliki karakter sebagai guru yang hebat jika membaca kitab-kitab Injil Sinoptik. Pheme Perkins menegaskan bahwa Yesus adalah seorang guru yang kharismatik. ${ }^{26}$ Bukti bahwa Yesus adalah seorang guru juga dapat dijumpai dalam kitab markus 9, dicatat bahwa Yesus tidak mau ditemui atau diganggu orang karena ia sedang mengajar.

${ }^{22}$ Price, Yesus Guru Agung, 35.

${ }^{23}$ Sudjana, Metode dan Teknik Pembelajaran Partisipatif, 72-73.

${ }^{24}$ B. S. Sidjabat, MengajarSecara Profesional (Bandung: Kalam Hidup, 2009), 178.

25 Price, Yesus Guru Agung, 35.

${ }^{26}$ Daniel Stevanus, Sejarah Pendidkkan (Bandung: Bina Media Informasi, 2009), 7. 


\section{Yesus Menggunakan Metode Yang Kreatif}

Menghasilkan cara mengajar yang kreatif meliputi banyak hal: sifat pribadi seorang guru dan pengenalan akan Tuhan dan firman-Nya, masa persiapan pelajaran, caranya ia merencanakan isi pelajaran, keterampilan-keterampilan dalam memakai beraneka macam metode mengajar dan hubungan pribadi dengan setiap murid. Seorang guru yang tidak berani berpikir secara kreatif ataupun belum pernah diajar secara kreatif akan menghadapi lebih banyak tantangan tatkala ia ingin mengubah cara mengajar nya. Namun, dengan kemauan yang sungguh, keberanian untuk mencoba sesuatu yang baru dan dengan pengarahan yang jelas dan bermutu, ia dapat juga menjadi seorang guru yang kreatif. 27

Guru merupakan unsur penting dalam proses belajar mengajar di bidang Pendidikan, serta memiliki tanggung jawab yang besar. Guru adalah Pembimbing siswa untuk mengenal, memahami dalam menghadapi semua yang berkaitan dengan pendidikan.

Seorang guru PAK harus memiliki tujuan yang jelas dalam mengajar serta memiliki hubungan yang dekat dengan peserta didik sehingga dapat mengenal karakter peserta didiknya dengan baik. Selain itu, guru PAK harus menggunakan metode yang menarik dalam menyampaikan firman Tuhan. ${ }^{28}$

Metode dapat diartikan sebagai "teknik," "cara," atau "prosedur." Metode mengajar adalah cara yang dipakai oleh seorang guru untuk menghubungkan kebenaran Alkitab dengan para muridnya. Dalam hal mengajar secara kreatif, metode mempunyai peran penting. Tak dapat disangkal bahwa efektivitas suatu pengajaran sangat ditentukan oleh metode yang dipakai dalam usaha mengkomunikasikan pelajaran yang sudah dipersiapkan. ${ }^{29}$ Berikut ini beberapa metode yang digunakan Yesus dalam Injil Markus.

\section{Metode Cerita}

Metode pembelajaran yang digunakan oleh Yesus dalam Injil Markus adalah: Diskusi, Tanya Jawab, Ceramah. Metode yang paling sering digunakan oleh Yesus dalam kitab Markus adalah metode cerita. Dalam hal ini penulis mengamati bahwa dalam kitab Markus, cerita adalah metode pengajaran paling sering dilakukan oleh Yesus. Metode cerita dapat diihat dalam pengajaran yang dikemas dengan bentuk perumpamaan (Lih. Mrk. 4:1-20, 21-25, 26-29, 30-33). Juga dalam Markus 12:1-12, Tuhan Yesus menceritakan tentang penggarap-penggarap kebun anggur daam bentuk perumpamaan (Band. Mat. 21:33-46).

Perlu juga diketahu bahwa metode cerita digunakan secara khusus oleh Yesus untuk menyampaikan pemberitaan Kerajaan Allah kepada orang banyak. Markus 4:33, menyatakan "dan tanpa perumpamaan Ia tidak berkata-kata kepada mereka. Metode cerita dilakukan Yesus dalam pembelajaran kepada orang banyak, juga kepada

\footnotetext{
${ }^{29}$ https://xaesar.wordpress.com/2009/05/06/mengajar-secara-kreatif.
} dan.html.

27https://xaesar.wordpress.com/2009/05/06/mengajar-secara-kreatif.

${ }^{28} \mathrm{http}: / /$ keziapujiantiparlan.blogspot.co.id/2014/06/penggunaan-metode-yang-kreatif- 
murid-murid-Nya (Mrk. 4:33). Berikut ada beberapa prinsip yang perlu diingat sewaktu bercerita.

1. Suara, roman muka, dan gerak-gerik yang nyata pada guru sewaktu bercerita menambahkan gairah, perhatian dan pengertian agar cerita itu benar-benar hidup. 2 . Pendahuluan cerita tidak boleh langsung memperkenalkan cerita itu. Contoh yang tidak baik: "Hari ini guru ingin bercerita tentang Goliat, raksasa besar yang melawan orang Israel." 3. Isi cerita dengan segala nama, tempat dan kejadian-kejadian harus dijiwai oleh guru sehingga dengan spontan dan akurat ia dapat menyampaikan cerita. Cerita tidak boleh dibaca. Keterampilan bercerita dengan baik menuntut kerja keras dan banyak latihan. 4. Percakapan langsung atau dialog antara oknum-oknum dalam cerita akan menjadikan cerita sungguh hidup bagi murid. 5. Cerita harus menggambarkan permulaan yang biasa, kemudian bertambah seru sampai kepada puncaknya yang akhirnya menurun dengan drastic. Cerita harus dihentikan pada puncaknya. 6. Pelajaran rohani tidak cocok ditambahkan pada akhir cerita tatkala para murid sudah puas mendengar cerita. Contoh yang tidak baik: "Nah, anak-anak, kita harus berani seperti Daud." Pelajaran rohani harus disisipkan dalam cerita pada bagian-bagian yang cocok agar perhatian murid tidak lenyap dan makna penting dari firman Tuhan sungguh-sungguh berkesan. ${ }^{30}$

Dikatakan J. M. Price, metode Tuhan Yesus yang khas, tidak dapat diraguragukan, adalah perumpamaan atau cerita. Metode ini lebih menonjol dari pada metode yang lain dalam pengajaran-Nya. ${ }^{31}$ Metode cerita sangat banyak ditemui dalam pengajaran Injil-injil Sinoptik. Itu dikarenakan Yesus sering mengajar dengan memakai perumpamaan-perumpamaan atau cerita. Seperti dikatakan oleh Price sangatlah menarik jika perhatikan betapa banyak Yesus memakai cerita dan perumpamaan dalam pengajaran-Nya. Kurang lebih seperempat dari kata-kata-Nya dicatat oleh Markus dan Lukas. ${ }^{32}$

Kemungkinan metode ini dipakai Tuhan Yesus karena metode cerita karena metode tersebut dapat dimengerti oleh banyak orang. Enklaar dan Homrighausen mengatakan, metode cerita mengikat perhatian karena menggambarkan hidup manusia dengan warna-warna yang serba indah. Tidak ada seorangpun yang tidak menggemari cerita yang tidak menarik. ${ }^{33}$

\section{Metode Ceramah}

Metode ceramah adalah penuturan bahan pelajaran secara lisan. Metode ini senantiasa bagus bila penggunaannya betul-betul disiapkan dengan baik, didukung oleh alat dan media, serta memperhatikan batas-batas kemungkinan penggunaannya. ${ }^{34}$ Ini sependapat dengan apa yang dikatakan oleh Wina Sanjaya, metode ceramah dapat diartikan sebagai cara menyajikan pelajaran melalui penuturan

\footnotetext{
${ }^{30}$ https://xaesar.wordpress.com/2009/05/06/mengajar-secara-kreatif.

${ }^{31}$ Price, Yesus Guru Agung, 108.

32Ibid., 109.

33I. H. Enklaar dan E. G. Homrighausen, Pendidikan Agama Kristen (Jakarta: BPK Gunung Mulia,

${ }^{34}$ A. E, Ratag, Diktat Kuliah: Strategi Pembelajaran Pendidikan Agama Kristen (Manokwari:
} 2011), 81. STT-ET, 2015), 11. 
secara lisan atau penjelasan langsung kepada sekelompok siswa. ${ }^{35}$ Metode ceramah merupakan metode yang sampai saat ini digunakan oleh setiap guru. Enklaar dan Homrighausen mengatakan metode ini sangat efektif, jikalau guru mempunyai bakat untuk membawakan pokok itu dengan suara yang nyaring dan bahasa yang menarik. ${ }^{36}$

Metode ceramah juga sering digunakan oleh Yesus sebagai metode untuk mengajar orang banyak bersama murid-murid-Nya seperti (Mrk. 13:1-2; 13:3-13; 13:14-23; 13:24-32). Di dalam ceramah itu dibentangkan keadaan yang akan timbul pada waktu kedatangan-Nya, yang kedua kali. Daniel Nuhamara mengatakan barangkali metode ini cukup sering dipakai dan dapat kita temukan dalam Injil-injil bagaimana Yesus menggunakan metode ini. Dengan metode ini Tuhan Yesus berusaha menyampaikan pengetahuan kepada murid-murid-Nya atau menafsirkan pengetahuan tersebut. ${ }^{37} \mathrm{Hal}$ yang sama juga dikatakan oleh Daniel, dengan metode ceramah Yesus berusaha menyampaikan pengetahuan kepada murid-murid-Nya atau menafsirkan pengetahuan tersebut. ${ }^{38}$ Daniel Stevanus mengutip pendapat dari Boehlke: melalui metode ceramah Yesus mengharapkan dua respons dari para pendengar-Nya, yakni pengertian mendalam dan perilaku baru.

Saat memakai metode ceramah seorang guru haruslah memperhatikan apakah murid dapat menyerap pelajaran itu dengan baik atau tidak. Sebab metode ceramah sangat memerlukan respon yang dari pendengar dan pengertian yang mendalam dari seorang murid.

Berikut ini beberapa kelemahan dan kelebihan yang penulis kutip dari Buku Dr. Wina Sanjaya, Strategi Pembelajaran Berorientasi Pada Standar Proses Pendidikan.

Kelebihan dari metode ceramah: 1). ceramah merupakan metode yang murah dan mudah untuk dilakukan. 2). Ceramah dapat menyajikan materi pelajaran yang luas. 3). Ceramah dapat memberi pokok-pokok materi yang perlu ditonjolkan. 4). Melalui ceramah, guru dapat mengontrol kelas, oleh karena sepenuhnya kelas merupakan tanggung jawab guru yang memberikan ceramah. 5). Organisasi kelas dengan menggunakan ceramah dapat diatur menjadi lebih sederhana. Kelemahan dari metode ceramah: 1). Materi yang dapat dikuasai oleh siswa sebagai hasil dari ceramah akan terbatas dari apa yang dikuasai guru. 2). Ceramah yang tidak disertai dengan peragaan dapat mengakibatkan terjadinya verbalisme. Verbalisme adalah penyakit yang sangat mungkin disebabkan oleh proses ceramah. 3). Guru yang kurang memiliki kemampuan bertutur dengan baik, ceramah sering dianggap sebagai metode yang membosankan. 4). Melalui ceramah, sangat ulit sekali untuk mengetahui apakah seluruh siswa sudah mengerti apa yang dijelaskan atau belum. ${ }^{39}$

35Wina Sanjaya, Strategi Pembelajaran Berorientasi Pada Standar Proses Pendidikan (Jakarta: Prenada Media Group, 2009), 147.

${ }^{36}$ I. H. Enklaar dan E. G. Homrighausen, Pendidikan Agama Kristen (Jakarta: BPK Gunung Mulia, 2011), 81.

37Daniel Nuhamara, Pembimbing PAK (Bandung: Jurnal Info Media, 2007), 138.

38Ibid., 10.

${ }^{39}$ Wina Sanjaya, Strategi Pembelajaran Berorientasi Pada Standar Proses Pendidikan, 147. 
Kelemahan dan kelebihan dari metode ceramah menunjukkan bahwa keberhasilan suatu guru dalam memakai metode sangat didukung oleh tujuan pengajaran guru tersebut. Tanpa memiliki tujuan yang ingin dicapai guru tidak akan berhasil dalam memakai metode tersebut. Tetapi juga agar dapat mengatasi beberapa kelemahan dari metode ceramah. Gulo memberikan solusinya:

Untuk meningkatkan keefektifan pengajaran dengan metode ceramah, maka disamping memanfaatkan keunggulan, juga diupayakan mengatasi kelemahankelemahannya. Strategi yang demikian disebut ceramah bervariasi. Disebut ceramah bervariasi karena dalam strategi ini terdapat beberapa komponen atau unsur yang masing-masing bervariasi. Komponen-komponen tersebut ialah, metode, media, penampilan dan bahan sajian. ${ }^{40}$

Itu sebabnya guru diharuskan untuk banyak belajar dan mempelajari bagian yang akan diajarkan. Lebih khusus ketika mengajar dengan memakai metode ceramah. Agar dapat menutupi kekurangan dari pengajarannya tersebut. Jika mengikuti apa yang dikatakan Gulo diatas itu berarti seorang guru harus memiliki gaya ceramah yang bervariasi sehingga dapat menutupi kelemahan dari metode tersebut.

\section{Metode Diskusi}

Metode diskusi merupakan metode yang juga sering Yesus pakai dalam mengajar. Beberapa contoh metode diskusi yang dibuat Yesus ialah ketika Dia mengajar. Terlebih khusus dalam Injil Markus 2:23-28; 6:30-44. Yesus mengajar sambil berdiskusi dengan murid-murid dan tak sering juga kepada orang banyak. Yesus memakai metode diskusi sebab metode ini sangat menarik. Seperti dikatakan oleh J. M. Price. Salah satu metode yang paling banyak dibicarakan sekarang, khususnya bagi orang-orang dewasa adalah metode diskusi. Metode ini digunakan Yesus dalam pengajaran-Nya. ${ }^{41}$

Metode diskusi kelompok menyangkut tanya jawab tetapi metode ini maju kepada pemecahan persoalan oleh kelompok. Metode ini jarang dipakai untuk anakanak kecil. Diskusi kelompok biasanya berkisar pada satu persoalan yang muncul dari kebenaran firman Tuhan. Metode ini paling cocok untuk langkah Lihat dan Buat. $^{42}$

Homrighausen mengatakan metode ini sangat indah. Hasilnya besar, jika dijalankan dengan kelompok yang kecil dengan pimpinan yang baik. ${ }^{43}$ Metode ini memang sangat menarik, sebab akan membawa murid untu lebih memahami isi dari pelajaran tersebut. Berdiskusi akan lebih membawa murid-murid dapat memecahkan suatu masalah lebih cepat dan lebih tepat.

Setelah persoalan diajukan oleh guru, murid-murid mulai menganalisa masalah dan memberikan masukan mereka masing-masing. Dengan pengarahan dari guru sebagai pemimpin, murid-murid dapat ditolong untuk memecahkan

40W. Gulo, Strategi Belajar Mengajar (Jakarta: Grasindo, 2002), 142.

41Price, Yesus Guru Agung, 122.

${ }^{42}$ https://xaesar.wordpress.com/2009/05/06/mengajar-secara-kreatif.

${ }^{43}$ I. H. Enklaar dan E. G. Homrighausen, Pendidikan Agama Kristen (Jakarta: BPK Gunung Mulia, 2011), 82. 
masalah tersebut berdasarkan kebenaran-kebenaran firman Tuhan yang baru dipelajari. Sebaiknya guru terlebih dahulu menyiapkan beberapa pertanyaan yang akan memimpin diskusi.44 Persiapan yang baik dalam metode ini akan menghasilkan pembelajaran yang lebih efktif.

\section{Metode Tanya Jawab}

Metode tanya jawab adalah salah satu metode yang tertua dan yang paling berpengaruh. Price mengatakan Socrates terkenal karena metode tersebut. ${ }^{45}$ Metode ini sangat sering dijumpai ditengah masyarakat juga disetiap guru. Metode tanya jawab ialah suatu cara penyajian bahan pelajaran dalam bentuk pertanyaan. Guru membuat suatu pertanyaan dan murid akan menjawabnya.

Penggunaan metode tanya jawab dilakukan oleh Yesus untuk mejadi bahan pemikiran dari pada murid-murid-Nya. Seperti contoh pertanyaan Yesus kepada murid-murid-Nya dan Petrus menjawab pertanyaan tersebut Markus 8:27-30. Yesus memberikan pertanyaan tersebut untuk mengetahui jawaban mereka. Itulah tujuan Yesus ada bersama-sama dengan murid-murid-Nya. Bertanya dan terus mendidik mereka dengan sebuah pengajaran yang benar.

Penulis mengutip apa yang dikatakan oleh W.P Merrill dalam buku Yesus Guru Agung J.M Price. Merrill mengatakan:

"Ia datang bukan untuk menjawab pertanyaan-pertanyaan, melainkan mengajukan pertanyaan-pertanyaan, bukannya untuk menentramkan jiwa orang-orang melainkan untuk menggoncangkan jiwa mereka, bukannya menjadikan kehidupan lebih enak, melainkan membuat kehidupan lebih terdidik. ${ }^{46}$

Yesus memberikan pertanyaan bukan saja mengetahui pertanyaan mereka tetapi juga untuk menarik perhatian mereka. Seperti dikatakan oleh J. M. Price: Salah satu tujuan dalam pemakaian metode ini ialah untuk menarik perhatian seseorang. ${ }^{47}$

Metode tanya jawab juga sangat membutuhkan keahlian dalam mempersiapkan suatu pertanyaan yang tepat dan menarik agar murid dapat merespon pertanyaan tersebut dengan baik. Seperti pertanyaan Yesus kepada murid-murid-Nya dengan suatu pertanyaan kata Yesus, kata orang siapakah Aku? Dan Petrus menjawabnya (Markus 8:27-30). Enklaar dan Homrighausen mengatakan jika dipakai dengan keahlian, pasti sangat memuaskan ${ }^{48}$

\section{Memberikan Keteladanan dalam hal Integritas bagi Guru}

Teladan-Nya sendiri sering melukiskan pula bagaimana hendaknya murid-murid bertindak: Yesus masuk ke rumah Zakheus dan duduk makan dengan pemungut cukai. Tatkala Yesus membasuhi kaki murid-murid-Nya bukankah itu teladan yang

\footnotetext{
${ }^{44}$ https://xaesar.wordpress.com/2009/05/06/mengajar-secara-kreatif.

45Price, Yesus Guru Agung, 117.

46Ibid., 119.

47Ibid., 117.

${ }^{48}$ Enklaar dan Homrighausen, Pendidikan Agama Kristen, 83.
} 
baik. $^{49}$ Guru PAK harus terus mengajarkan kebenaran dan memiliki komitmen dalam mengajar meskipun dengan fasilitas yang tidak memadai. Seorang guru PAK juga harus menjadi teladan dalam perkataan dan perbuatan seperti yang telah diajarkan Tuhan Yesus. ${ }^{50}$

Cara Yesus mengajar sangat menarik perhatian orang-orang pada zaman-Nya, sehingga mereka berbondong-bondong untuk mendengar pengajaran-Nya. Yesus mengajar bukan hanya teori-teori bagaimana orang mendapat keselamatan, tetapi Ia sendirilah sumber keselamatan itu. Yesus adalah guru yang tidak ada taranya, seluruh kehidupan Yesus adalah pengajaran yang mulia sampai pada akhir hayatNya untuk menyelamatkan manusia dari segala dosa. ${ }^{51}$ Yesus adalah sosok Guru Agung bagi kita. Setiap pendidik yang ingin berhasil dalam mengajarkan kebenaran Firman Allah haruslah senantiasa belajar kepada Yesus. Yesus memiliki banyak keteladanan sebagai Guru Agung yang dapat kita teladani.

\section{KESIMPULAN}

Gaya mengajar Yesus mampu menarik perhatian banyak orang pada saat itu. Jika diperhatikan dalam kitab Injil-injil banyak orang sudah mulai bosan dengan cara mengajar dari pada guru-guru zaman itu. Reaksi dari pada orang-orang dapat dilihat dalam catatan Injil Markus. Mereka takjub mendengar pengajaran-Nya, sebab Ia mengajar mereka sebagai orang yang berkuasa, tidak seperti ahli-ahli Taurat. Orang banyak yang besar jumlahnya mendengarkan Dia dengan penuh minat (Mrk. 1:22; 13:37). Jika diamati lebih dalam, apa yang dikatakan oleh Markus sangatlah menarik. Karena dalam ayat 22 mengatakan orang banyak yang jumlahnya sangat besar mendengarkan Dia. Itu berarti bahwa Yesus mengajar dengan sangat menarik, gaya pola berbicaranya sangat bagus. Kemungkinan metode yang digunakan oleh Yesus berbeda dengan guru-guru pada zaman itu.

Metode mengajar yang dipakai Tuhan Yesus yang menarik dengan memakai berbagai-bagai cara yang berbeda-beda menjadikan Yesus sebagai pusat metode pengajaran. Metode pengajaran Tuhan Yesus sangat baik untuk dicontoh oleh guruguru sekarang ini. Sebab metode mengajar yang menarik akan menyenangkan para murid. Sebaliknya jika metode mengajar yang dipakai guru tidak menarik akan membuat murid menjadi bosan dalam mengikuti pembelajaran.

\section{REFERENSI}

Alkitab. 2010. Jakarta: Lembaga Alkitab Indonesia.

A. E, Ratag, Diktat Kuiah Strategi Pembelajaran Pendidikan Agama Kristen. Manokwari: STT-ET, 2015.

Awulle, Clartje Silvia E. "Penyelenggaraan Pendidikan Kristen Sebagai Pemenuhan Hak Asasi Manusia.” SIKIP Jurnal Pendidikan Agama Kristen 1, no. 1 (2020): 25-37.

\footnotetext{
${ }^{49}$ Desti Samarenna and Harls Evan R Siahaan, "Memahami Dan Menerapkan Prinsip Kepemimpinan Orang Muda Menurut 1 Timotius 4:12 Bagi Mahasiswa Teologi,” BIA': Jurnal Teologi dan Pendidikan Kristen Kontekstual 2, no. 1 (2019): 1-13, http://www.jurnalbia.com/index.php/bia. ${ }^{50}$ Paulus Lilik Kristianto, Prinsip dan Praktik Pendidikan Agama Kristen (Yogyakarta: ANDI, t.t), 13.

51John M. Nainggolan, Menjadi Guru Agama Kristen (Generasi Info Media), 19.
} 
Benyamin, Prislika issak, Yogi Mahendra, and Donald Samuel Slamet Santosa. "Metode Pembelajaran Untuk Meningkatkan Prestasi Belajar Siswa Pada Mata Pelajaran Pendidikan Agama Kristen: Studi Meta Analisis.” SOTIRIA (Jurnal Teologi dan Pelayanan Kristiani) 3, no. 1 (2020): 25-35. http://sttpaulusmedan.ac.id/ejournal/index.php/sotiria/article/view/17.

Cole, A. R. Ensiklopedi Alkitab Masa Kini. Jakarta: Yayasan Komunikasi Bina Kasih/OMF, 2000.

Geldenhuys, N. J. Ensiklopedi Alkitab Masa Kini Jilid I. Jakarta: Yayasan Komunikasi Bina Kasih/OMF, 2000.

Guthrie, Donald. Pengantar Perjanjian Baru. Surabaya: Momentum, 2010.

Gulo, W. Strategi Belajar Mengajar. Jakarta: Grasindo, 2002.

Hartono, Handreas. "Membentuk Karakter Kristen Pada Anak Keluarga Kristen." KURIOS (Jurnal Teologi dan Pendidikan Agama Kristen) 2, no. 1 (2014): 62-69. www.sttpb.ac.id/e-journal/index.php/kurios.

Hasugian, Johanes Waldes. "Kurikulum Dan Pembelajaran Warga Jemaat Dewasa Di Gereja." KURIOS (Jurnal Teologi dan Pendidikan Agama Kristen) 5, no. 1 (2019): $36-53$.

Hasugian, Johanes Waldes. Menjadi Guru PAK Profesional Melalui Supervisi Pendidikan Agama Kristen. 2nd ed. Medan: CV. Mitra, 2016.

Homrighausen, E. G. \& I. H, Enklaar. Pendidikan Agama Kristen. Jakarta: BPK Gunung Mulia, 2011.

https://xaesar.wordpress.com/2009/05/06/mengajar-secara-kreatif

http://keziapujiantiparlan.blogspot.co.id/2014/06/penggunaan-metode-yangkreatif-dan.html

http://www.eurekapendidikan.com/2014/10/definisi-metode-menurut-paraahli.html.

http://www.sabda.org/sejarah/artikel/pengantar_full_life_markus.htm.

http://pepak.sabda.org/25/nov/2004/anak_metode_mengajar_yesus.

Kristianto, Lilik Paulus. Prinsip dan Praktik Pendidikan Agama Kristen. Yogyakarta: ANDI, t.t.

Nuharmara, Daniel. Pembimbing PAK. Bandung: Jurnal Info Media, 2007.

Samarenna, Desti, and Harls Evan R Siahaan. "Memahami Dan Menerapkan Prinsip Kepemimpinan Orang Muda Menurut 1 Timotius 4:12 Bagi Mahasiswa Teologi." BIA': Jurnal Teologi dan Pendidikan Kristen Kontekstual 2, no. 1 (2019): 1-13. http://www.jurnalbia.com/index.php/bia.

Sanjaya, Wina. Strategi Pembelajaran Berorientasi Pada Standar Proses Pendidikan. Jakarta: Prenada Media Group, 2009.

Sidjabat, S. B. Menjadi Guru Profesional Bandung: Yayasan Kalam Hidup, 2000.

Sinaga, Crosnoy Donna. Sripsi Studi Eksegesis Theologis Model-model Pertanyaan Allah dan Refleksi Theologisnya Menurut Kejadian 3:8-13. Jogjakarta: STTII, 2007.

Stevanus, Daniel. Sejarah Pendidkkan. Bandung: Bina Media Informasi, 2009.

Sudjana, D. H. Metode dan Teknik Pembelajaran Partisipatif. Bandung: Falah Produktion, 2001.

Swift, Graham. C. E. Tafsiran Alkitab Masa Kini. Disunting oleh Harun Hadiwijonon. Jakarta: Yayasan Bina Kasih, 2012.

Tenney, C. Merrill. Survei Perjanjian Baru. Malang: Gandum Mas, 2009. 